\section{Learning from Romanian women's struggle to manage their fertility}

The commentary by Horga et al. ${ }^{1}$ on the consequences of Ceauşescu's attempt to ban abortion in Romania is a stark reminder of what happens when women are prevented from accessing safe and legal means to end problem pregnancies. In short, they end their pregnancies using means that are unlawful and/or unsafe, sometimes with tragic consequences.

Although it is difficult to compare any country today with the repressive, restrictive climate of Romania in the 1960 s and 1970s, a reminder of the contribution that adequate birth control, including abortion, makes to women's health is important. Politicians in Ireland - and the UK, since abortion is still outlawed in the Northern Ireland counties that it governs - would do well to take note.

The recent death of a woman who was denied a pregnancy termination in Ireland $^{2}$ has focused international attention on its abortion ban. One might ask why, when one considers Romania, there have not been more deaths in Ireland? The answer is simple. Although abortion is unlawful in Ireland, Irish women have found their own ways of accessing services.

For thousands of Irish women, the path to an abortion involves a relatively cheap flight to Britain and treatment provided by a not-for-profit clinic run by a charity. At British Pregnancy Advisory Service (bpas) clinics, especially in Liverpool, Birmingham and London, Irish visitors are so 'normal' that a special range of literature is provided, explaining how to care for themselves as they travel home.

Other women rely on the internet to obtain medicines that are safe for them to use but illegal to obtain. Clearly, there are risks with internet supply, not least that the medication may not be authentic, and could even be harmful. Internet sites such as 'Women on Web' (https://www.womenonweb. org/) have become a vital source of safe medication for women living where safe, legal abortion is unavailable. And the widespread availability of the abortifacient misoprostol as treatment for gastric ulcers is another lifeline, especially where it is available in local pharmacies.
Women still die from abortion bans. International agencies publish estimates routinely. Governments record their horror and pledge to make motherhood safer. At the London Summit on Family Planning in July 2012, the British Prime Minister, David Cameron, responded to estimates that an unplanned pregnancy is conceived every 10 seconds by announcing $£ 500$ million in aid to increase international access to contraceptives. ${ }^{3} \mathrm{He}$ told government representatives from around the world: "Women should be able to decide freely, and for themselves, whether, when and how many children they have ... When a woman is prevented from choosing when to have children it's not just a violation of her human rights, it can fundamentally compromise her chances in life, and the opportunities for her children". 4

Yet in Northern Ireland and Ireland, women are denied that choice because they are denied access to abortion. European politicians find it easy to understand the importance of safe contraception and abortion in countries far away; they find it less easy to understand the importance of reproductive choice in their own countries. Romania is a good European example of why abortion bans should be regarded as being as perverse and as archaic as the rest of Ceauşescu's policies.

\section{Ann Furedi}

Chief Executive, British Pregnancy Advisory Service (bpas), London, UK; ann.furedi@bpas.org

Competing interests The author is Chief Executive of British Pregnancy Advisory Service (bpas).

Journal of Family Planning and Reproductive Health Care 2013:39:150.

doi:10.1136/jprhc-2013-100594

\section{REFERENCES}

1 Horga M, Gerdts C, Potts M. The remarkable story of Romanian women's struggle to manage their fertility. J Fam Plann Reprod Health Care 2013;39:2-4.

2 Houston M. Investigations begin into death of woman who was refused an abortion. BMJ 2012;345:e7824.

3 Prime Minister's Speech on Family Planning. 11 July 2012. http://www.number10.gov.uk/news/ prime-ministers-speech-on-family-planning/ [accessed 15 January 2013].

4 Tran M. Rich countries pledge \$2.6bn for family planning in global south. 11 July 2012. http://www.guardian.co.uk/ global-development/2012/jul/11/ rich-countries-pledge-family-planning-women [accessed 15 January 2013]. 